\title{
COVID-19 HEALTH EDUCATION DEVELOPMENT USING “SMART PUNAKAWAN" IN SURAKARTA
}

\author{
Eti Poncorini Pamungkasari'), Bulan Hermasari'), Hartono' ${ }^{1}$,Sri Mulyani' ${ }^{2}$, \\ Sri Parwatiningsi²), Lely Tri Pangesti3), Arsyi Ramadhan') \\ 1)Faculty of Medicine, Universitas Sebelas Maret \\ ${ }^{2)}$ Vocational Program, Universitas Sebelas Maret \\ 3) Masters Program in Public Health, Universitas Sebelas Maret
}

\begin{abstract}
Background: The ongoing pandemic has clearly shown community that there is a need to further strengthen health promotion to elevate knowledge and engage COVID-19 prevention behavior in community. Studies report a comprehensive empirical investigation of the nature and correlates of anti-mask attitudes during the COVID-19 pandemic. This represents the low level of public understanding of the importance of preventing COVID-19 behavior. This study aimed to develop health education strategy specific COVID-19 prevention behavior.
\end{abstract}

Subjects and Method: This was a qualitative study. Situation analysis is carried out as an early stage of developing a health education strategy. The key informants were 13 people consisted of epidemiolog, medical practitioners, and public health staffs. The data were collected by focus group discussion (FGD). FGD was carried out by online meeting on zoom. An assissted FGD instrument was used to probe prevention of COVID-19 transmission.

Results: The health education strategy on COVID-19 prevention that will be developed needs to include cultural elements so that people are more receptive. The use of "wayang" (Indonesian traditional puppet) figures as a role model, named Punakawan, is considered an extension of health workers to convey health messages about COVID-19. The FGD determined the use of the term "SMart-Punakawan" as a method of health promotion. Punakawan has the meaning of "servant" of the knights but has an important role as an advisor, so it really represents the function of health workers. The educational content in this health promotion model focuses on the importance of vaccination and reemphasizes the importance of washing hands, wearing face masks, maintaining distance, as prevention of COVID-19 transmission. The media used are videos, brochures, and banners. It is hoped that with this health promotion model it can reach a wider community.

Conclusion: Smart-Punakawan has been developed as a health education strategy regarding COVID-19 with cultural wisdom to approach the community in order to reduce the transmission of COVID-19.

Keywords: "Smart Punakawan", COVID-19, health promotion model

Correspondence:

Lely Tri Pangesti. Masters program in Public health, Universitas Sebelas Maret. Jl. Ir. Sutami 36A, Surakarta 57126, Central Java. Email: lellytrip@gmail.com. Mobile: 082223360202. 